\title{
Normalized Dryness Built-up Index (NDBI) to Detect Settlement Change in Buleleng Sub-District
}

\author{
Muhammad Rahman ${ }^{1 *}$, A Sediyo Adi Nugraha ${ }^{1}$ \\ 1 Universitas Pendidikan Ganesha, Indonesia \\ *e-mail: muhamad.rahman@undiksha.ac.id
}

Article history: Received 15 December 2020; Accepted 31 March 2021; Available online 30 April 2021

\begin{abstract}
This research aims to find out the development of settlements that occur over the next 20 years. Monitoring the development of settlements is carried out by remote sensing methods using Landsat 7 ETM+ imagery and Landsat 8 OLI imagery. Landsat 7 ETM+ used in 2000, and Landsat 8 OLI used in 2019. The algorithm is used to identify settlement development using the Normalized

\section{Keywords:}

NDBI; Landsat 7 ETM+;

Landsat $\quad 8 \quad 0 \mathrm{LI}$;

Settlement Change Dryness Built-up Index (NDBI). This algorithm uses two bands, such as Near-infrared and shortwave infrared, to calculate. The results showed that the growth of settlements occurred very significant because, in 2000, the number of settlements amounted to 628.2 hectares and in 2019 amounted to 1891.8 hectares. The increase in settlements occurred throughout the region in the Buleleng sub-district. Therefore, it can be concluded that NDBI can be used to monitor the development of settlements and the increase in settlements occurring as much as $28 \%$ over 20 years.
\end{abstract}

Copyright @ Universitas Pendidikan Ganesha. All rights reserved.

\section{Introduction}

The increase in population is an uncontrollable factor in the development of the region. The development of the area will affect the condition of the regional infrastructure and the planning of the region (Arsandi et al., 2017; Subki, 2018). That discrepancy will result in rapid land cover changes, reduced green open space, and rising land surface temperatures (Fawzi, 2017; A Sediyo Adi Nugraha et al., n.d.; Sadali, 2014; Septiani et al., 2019). Therefore, it is necessary to monitor with efficient and fast methods and see the changes in the development of urban areas temporally. Remote Sensing is an appropriate method for monitoring the development of urban areas temporally. These remote sensing capabilities are supported by spatial resolution conditions and appropriate channels to monitor urban change (Sutanto, 1986, 1987). Besides, remote sensing advantages can be used to monitor shoreline changes, surface temperature measurements, and urban heat island (Hasan et al., 2019; A. S.A. Nugraha et al., 2019; A Sediyo Adi Nugraha, 2019; A Sediyo Adi Nugraha \& Atmaja, 2020; Septiani et al., 2019).

The appropriate formula for monitoring urban area changes is to use Normalized Dryness Built-up Index (NDBI) using remote sensing data. This algorithm will look at urban areas that are settlements so that it can be known the land cover changes that have occurred over a while. Therefore, monitoring changes in urban areas for 20 years so that it is known the distribution that has occurred to the needs of green open areas. This period shows the relationship between urban area changes and the increasing population development in the Buleleng sub-district. The 
population growth in the Buleleng sub-district increased by $1.89 \%$ due to the influence of the attractiveness of education and the economy. Also, the density of settlements that occurred to date resulted in increased urban temperature by one degree (Nugraha \& Atmaja, 2020).

The speed of change and improvement leads to the importance of monitoring urban area changes through remote sensing data capable of providing comprehensive and efficient area coverage at different times. Therefore, this study aims to know how remote sensing data can determine changes in urban areas through the NDBI method. This research can be added to providing reference regarding the utilization of NDBI methods for settlement monitoring.

\section{Method}

\section{Study Area}

This research was conducted in the Buleleng sub-district, which is located at $08^{\circ} 03^{\prime} 40^{\prime \prime}$ up to $08^{\circ} 23^{\prime} 00^{\prime \prime} \mathrm{S}$ and $114^{\circ} 25^{\prime} 55^{\prime \prime}$ to $115^{\circ} 27^{\prime} 28^{\prime \prime} \mathrm{BT}$. Buleleng sub-district is taken as a research site because the Buleleng sub-district is currently under construction, and there is an improvement in education. Buleleng sub-district economic development has increased due to higher population growth (Risma Pandapotan Sitorus et al., 2012) (Purwahita, 2015).

\section{Remote Sensing Data}

The remote sensing image used is Landsat imagery. Landsat imagery used includes Landsat 7 ETM+ and Landsat 8 OLI. The Landsat 7 ETM+ image will be used for July 2000, while the Landsat 8 OLI/TIRS image will be used for May 2019. As for both imagery, Landsat has different types of bands. Citra Landsat 7 ETM+ will use Band 4 and band 7, while Landsat 8 OLI/TIRS imagery uses band five and band 6 . The month difference in each image did not affect the analysis.

\section{Radiometric Correction}

Landsat 7 ETM+ and Landsat 8 OLI have the first correction process. The corrections process have Radiometric and Atmospheric for both images. The Radiometric correction is performed as in equations (1) and (2). NASA developed the equation following their respective imagery handbooks (Department of the Interior U.S. Geological Survey, 2016; U.S. Geology Survey Department, 2010).

$$
P \lambda_{\text {Landsat } 7 \text { ETM+ }}=\frac{\Pi \cdot L \lambda \cdot d^{2}}{E S U N \lambda \cdot \operatorname{Cos} \theta s}
$$

Equation (1) where, $\Pi$ is Konstanta mathematical values with $3.14 ; L \lambda$ is radiance value from Landsat $7 \mathrm{ETM}+; d$ is earth-sun distance can be obtained from metadata Landsat 7 ETM+; ESUN Mean solar exo-atmospheric irradiances can be obtained from Handbook Landsat 7 ETM+, and $\theta s$ is solar zenith angle can be obtained from metadata Landsat 7 ETM+.

$$
P \lambda_{\text {Landsat } 8 \text { oLI }}=M_{p} * Q_{c a l}+A_{p}
$$

Equation (2) where, $M_{p}$ is reflectance multiplicative value from Landsat 8 OLI can be obtained from metadata; $A_{p}$ is reflectance additive value from Landsat 8 OL can be obtained from metadata, and $Q_{c a l}$ is Landsat 8 spectral band.

This process is used to convert pixel values into radian to reflectan values. Furthermore, cropping imagery is done to adjust the research area, and processing is assisted by using the ENVI application.

Figure 1 shows a flow chart of research in which the data used is the Landsat image as the primary data in this research. 


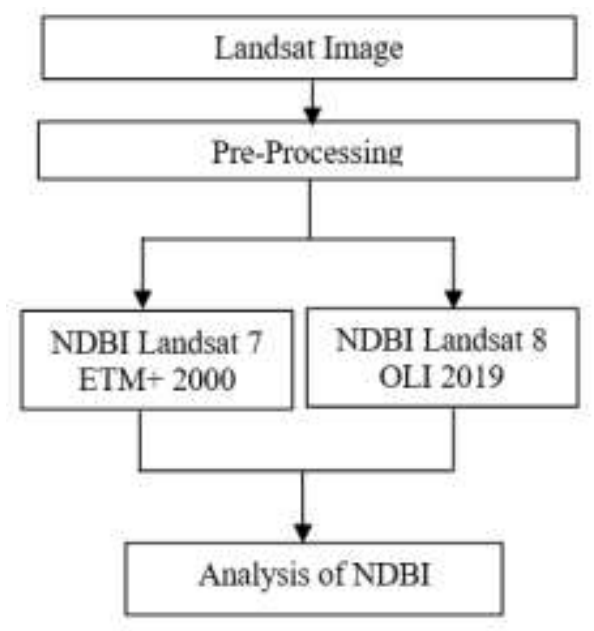

Fig. 1. Flowchart Research

\section{Atmospheric Correction}

In the second phase, the atmospheric correction process uses the value of water pixels as a correction value due to atmospheric disturbances caused when recording remote sensing imagery. The method used to perform the atmospheric correction process is known as the relative atmospheric correction method developed by Chaves (Chavez, 1988).

The Chaves method is known as a relative atmospheric correction called Dark Pixel Subtraction (DOS) because it does not consider factors of atmospheric disturbance such as visibility, the value of water vapor content, and air pollution content. Equation (3) below is the algorithm used in atmospheric correction in this research.

$$
\text { DOS }=\text { band }-(\text { Mean }-(2 * \text { Standar Deviasi })
$$

The band is spektral Landsat; mean and standar deviation value water objetc can be obtained from training samples.

\section{Normalized Dryness Built-up Index (NDBI)}

Normalized Difference Built-up Index (NDBI) indicates the density of the settlements. NDBI is very sensitive to land or open land. This algorithm was chosen because it is the most commonly used transformation to examine the awakened land index. NDBI is an algorithm developed by Zha (Zha et al., 2003). The NDBI algorithm is shown in equation (4).

$$
\text { NDBI }=((\text { NIR-SWIR }) /(N I R+S W I R)) \text {. }
$$

NIR is a Near-Infrared spectral band from Landsat 7 ETM+ and Landsat 8 OLI, and SWIR is a Shortwave Infrared spectral band from Landsat 7 ETM+ and Landsat 8 OLI.

\section{Result and Discussion}

The analysis of changes in urban areas occurs very significantly, and it corresponds to the results of remote sensing data processing. In 2000 the location of urban settlement activities was centered close to the beach. While in the southern and western regions, there has been no development of education and tourism, so the change in land cover did not change at that time. The port influenced the change of urban settlements as an economic center and had accessibility 
that was easily accessible at the time. The area became an attraction as an economic improvement and the development of urban settlements in the suburbs.

Over the past 20 years, the changes show significant differences (Figure 2), where formerly farmland areas are now transformed into urban settlements. The influence of differences in urban settlement development in the Buleleng sub-district is due to increased population growth. The increase occurred because of educational facilities and infrastructure that became the community attraction to come. Besides, the Buleleng Regency tourist sector is growing and has appeal to domestic and international tourists related to the heritage of historical buildings and dolphin sightings.

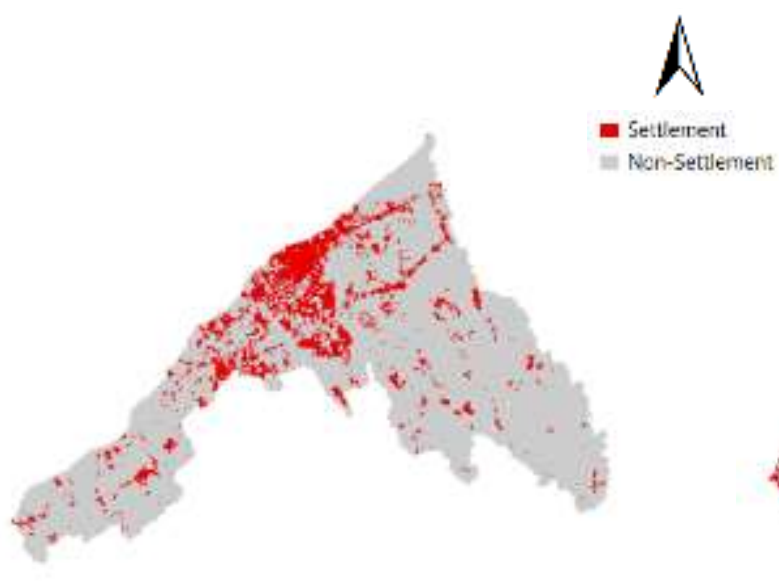

(a)

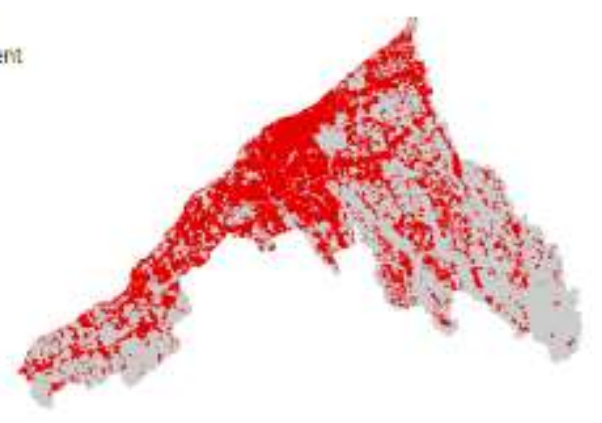

(b)

Fig. 2. NDBI Result (a) Landsat 7 ETM+/2000 and (b) Landsat 8 OLI/2019

The classification of the use of NDBI is divided into two; settlements and non-settlements. In 2000 the total number of settlements amounted to 628.2 Hectares, while in 2019 increased to 1891.8 Hectares. The increase occurred in the southern, western, and eastern regions of the Buleleng Sub-district. The planning regarding the development of settlements in the Buleleng sub-district is not controlled. Nevertheless, residential growth can be laid out because the eastern region is an economic area, while the western area is a tourist area, and the south is an Education area, so the southern region changes faster than other areas.

That significant change has a negative impact. The impacts are caused by the change, such as flooding in urban areas during the rainy season. Besides, the reduction of agricultural land becomes residential land and impacts the increasing temperature of urban settlements. This phenomenon has always existed in the development of urban areas. It can be mentioned that the use of NDBI methods in monitoring changes in urban areas provides accurate information such as patterns and distribution locations. It is hoped that this NDBI method can be used to assist in urban development planning activities in the preparation of the Regional Spatial Plan (RTRW).

\section{Conclusion}

The remote sensing method through the NDBI algorithm can show the distribution of settlement improvement locations from 2000 to 2019. An increase of $28 \%$ over 20 years. The distribution of settlement sites occurs throughout the Buleleng sub-district, especially areas close to the economic center. This research still has flaws, so it is necessary to compare with other methods so that pixels that are indeed settlements can be known through such comparisons. 


\section{Daftar Pustaka}

Arsandi, A., R, D., Ismiyati, I., \& Hermawan, F. (2017). Dampak Pertumbuhan Penduduk Terhadap Infrastruktur Di Kota Semarang. Jurnal Karya Teknik Sipil S1 Undip, 6(4), 1-14.

Chavez, J. (1988). Animproved dark-object subtraction technique for atmospheric scattering correction of multispectral data. Remote Sensing of Environment, 24, 159-279.

Department of the Interior U.S. Geological Survey. (2016). Landsat 8 Data Users Handbook. In Nasa (Vol. 8, Issue June).

Fawzi, N. I. (2017). Mengukur Urban Heat Island Menggunakan Penginderaan Jauh, Kasus Di Kota Yogyakarta ( Measuring Urban Heat Island using Remote Sensing, Case of Yogyakarta City ). Majalah Ilmiah Globe, 19(2), 195-206.

Hasan, M. Z., Citra, I. P. A., \& Nugraha, A. S. A. (2019). Monitoring Perubahan Garis Pantai Di Kabupaten Jembrana Tahun 1997 - 2018 Menggunakan Modified Difference Water Index ( Mndwi ) Dan Digital Shoreline Analysis System ( DSAS ). Jurnal Pendidikan Geografi Undiksha, 7(3), 93-102.

Nugraha, A. S.A., Gunawan, T., \& Kamal, M. (2019). Comparison of Land Surface Temperature Derived from Landsat 7 ETM+ and Landsat 8 OLI/TIRS for Drought Monitoring. IOP Conference Series: Earth and Environmental Science, 313(1), 0-10. https://doi.org/10.1088/1755-1315/313/1/012041

Nugraha, A Sediyo Adi. (2019). Pemanfaatan Metode Split-Windows Algorithm ( SWA ) pada Landsat 8 Menggunakan Data Uap Air MODIS Terra (The Application of Split-Windows Algorithm (SWA) Methods on Landsat 8 Using Modis Terra Water Vapor). Geomatika, 25(1), 9-16. https://doi.org/http://doi.org/10.24895/JIG.2019.25-1.877

Nugraha, A Sediyo Adi, \& Atmaja, D. M. (2020). Pemanfaatan Citra Penginderan Jauh MultiTemporal Penggunaan Lahan Di Kabupaten Buleleng ( The Application of Multi-Temporal Remote Sensing Images to Detect Urban Heat Island ( UHI ) for Land use Changes in Buleleng District ). Majalah Ilmiah Globe, 22(2), 71-82.

Nugraha, A Sediyo Adi, Kamal, M., \& Gunawan, T. (n.d.). Modification Of Temperature Vegetation Dryness Index (TVDI) Method For Detecting Drought With Multi-Scale Image. Unpublished.

Purwahita, R. (2015). Strategi Pengembangan Wisata Bahari di Pantai Lovina Kecamatan Buleleng Kabupaten Buleleng (Akpar "Kerta Wisata” Denpasar). 13, 29-36.

Risma Pandapotan Sitorus, S., Leonataris, C., Dyah Retno Panuju, dan, Ilmu Tanah dan Sumberdaya Lahan, D., Pertanian IPB, F., \& Meranti Kampus, J. (2012). Analysis of Land Use Change Pattern and Regional Development in Bekasi City, West Java Provinces. J. Tanah Lingk, 14(1), 21-28.

Sadali, M. I. (2014). Trend Perkembangan Penduduk Dan Implikasinya Terhadap Kebutuhan Rth (Ruang Terbuka Hijau) Di D.I. Yogyakarta. Prosiding Pertemuan Imiah Tahunan (PIT) Ikatan Geograf Indonesia, 366-379.

Septiani, R., Citra, I. P. A., \& Nugraha, A. S. A. (2019). Perbandingan Metode Supervised Classification dan Unsupervised Classification terhadap Penutup Lahan di Kabupaten Buleleng. Jurnal Geografi: Media Informasi Pengembangan Dan Profesi Kegeografian, 16(2), 90-96. https://doi.org/10.15294/jg.v16i2.19777

Subki, R. M. (2018). Dampak Pertumbuhan Penduduk Terhadap Perkembangan Ruang Kota Sangatta. Jurnal Arsitektur ZONASI, 1(1), 16. https://doi.org/10.17509/jaz.v1i1.11532

Sutanto. (1986). Pengideraan Jauh Jilid I.

Sutanto. (1987). Penginderaan Jauh Jilid II. Gadjah Mada University Press.

U.S. Geology Survey Department. (2010). Landsat 7 Science Data Users Handbook. https://doi.org/10.1001/archinternmed.2011.606

Zha, Y., Gao, J., \& Ni, S. (2003). Use of normalized difference built-up index in automatically mapping urban areas from TM imagery. International Journal of Remote Sensing, 24(3), 583-594. https://doi.org/10.1080/01431160304987. 